\title{
VALIDASI METODA FRAP MODIFIKASI PADA PENENTUAN KANDUNGAN ANTIOKSIDAN TOTAL DALAM SAMPEL MANGGA DAN RAMBUTAN
}

\author{
Yefrida $^{a^{*}}$, Nor Ashikin $^{\mathrm{a}}$, Refilda $^{\mathrm{b}}$ \\ ${ }^{a}$ Laboratorium Kimia Analisa Terapan, Jurusan Kimia FMIPA, Universitas Andalas Jurusan \\ Kimia FMIPA Unand, Kampus Limau Manis, 25163 \\ ${ }^{b}$ Laboratorium Kimia Lingkungan, Jurusan Kimia FMIPA, Universitas Andalas Jurusan Kimia \\ FMIPA Unand, Kampus Limau Manis, 25163 \\ Email: yefanwar@gmail.com
}

\begin{abstract}
Validation of modified FRAP method to determine total antioxidant content in mango and rambutan sample have been done. Total antioxidan content in sampel is presented as Gallic Acid Equivalent (GAE). Modified FRAP method using $\mathrm{FeCl}_{3}$ as oxidizing agent and orthophenantroline as complexan, which produce complex compounds of $\left[\mathrm{Fe}\left(\mathrm{C}_{12} \mathrm{H}_{8} \mathrm{~N}_{2}\right)_{3}\right]^{+2}$ sorrel coloured. Validation parameters are obtained in this research are $\mathrm{r}=0.999, \mathrm{R}^{2}=0.998$, LoD $3.13 \times 10^{-6} \mathrm{M}$ and LoQ $1.04 \times 10^{-5} \mathrm{M}$. While RSD and recovery in the sample mango and rambutan were $1.15 \%, 1.34 \%$ and $96.31 \%, 97.72 \%$, respectively. Based on the value of the validation parameters, it can be concluded that this method can be used for determination of total antioxidant content in the mango and rambutan samples.
\end{abstract}

Keywords: antioxidants, modified FRAP method, validation method

\section{PENDAHULUAN}

Pada umumnya buah-buahan merupakan sumber dari senyawa-senyawa yang bersifat antioksidan seperti senyawa fenolik, vitamin, karotenoid dan mineral yang berperan dalam potensi kemopreventifnya ${ }^{[1]}$.

Antioksidan adalah zat yang apabila terdapat dalam makanan atau minuman dapat mencegah oksidasi substrat. Antioksidan dapat melindungi tubuh dari berbagai jenis kerusakan oksidatif yang disebabkan oleh spesies oksigen reaktif. Antioksidan dapat digunakan untuk mencegah berbagai penyakit seperti kanker, diabetes, arthritis, shock dan percepatan proses penuaan ${ }^{[2]}$.

Antioksidan ada yang bersifat alami yaitu yang berasal dari bahan alam ada juga yang bersifat sintetik. Antioksidan alami banyak terdapat pada tumbuh-tumbuhan baik pada bagian buah, batang, akar dan daun, seperti yang terdapat pada Teucrium polium and Stachys iberica ${ }^{[3]}$, pohon apel ${ }^{[4]}$, buah berry ${ }^{[5]}$, sereal $^{[6]}$, buah $\operatorname{segar}^{[7]}$, delima ${ }^{[8]}$, coklat $^{[9]}$, batang cherry ${ }^{[10]}$, blueberry ${ }^{[11]}$, cabe ${ }^{[12]}$ dan banyak lagi tumbuhan lainnya.

Metoda-metoda yang telah dikembangkan untuk penentuan kandungan antioksidan dalam sampel antara lain dengan metoda spektrofometri diantaranya adalah DPPH, ABTS, CUPRAC, ORAC dan FRAP ${ }^{[13-14]}$, metoda elektrokimia, contoh silver nanoparticle-based method ${ }^{[15]}$, voltametri ${ }^{[16]}$, liquid core capillary cell (LWCC) ${ }^{[17]}$, dan metoda kromatografi contoh LC/MS-MS ${ }^{[7]}$, on-line HPLC-UV-ABTS radical scavenging dan LC-UV-ESI-MS ${ }^{[18-19]}$.

Pemilihan metoda yang akan digunakan dalam penentuan antioksidan sangat tergantung pada ketersedian bahan dan peralatan penelitian. Metoda yang paling banyak digunakan adalah metoda spektrofotometri. Hal ini tentu saja disebabkan oleh peralatan utama yang dibutuhkan yaitu spektrofotometer pada 
umumnya tersedia pada laboratorium yang sederhana sekalipun.

Metode FRAP atau Ferric Reducing Antioxidant Power adalah salah satu metoda penentuan kandungan antioksidan secara spektrofotometri yang berdasarkan pada reduksi analog ferroin, kompleks $\mathrm{Fe}^{3+}$ dari tripiridiltriazin $\mathrm{Fe}(\mathrm{TPTZ})^{3+} \quad$ menjadi kompleks $\mathrm{Fe}^{2+}, \mathrm{Fe}(\mathrm{TPTZ})^{2+}$ yang berwarna biru intensif oleh antioksidan pada suasana asam. Hasil pengujian diinterpretasikan dengan peningkatan absorbansi pada panjang gelombang $593 \mathrm{~nm}$ dan dapat disimpulkan sebagai jumlah $\mathrm{Fe}^{2+}$ (dalam mikromolekular) ekuivalen dengan antioksidan standar. Penentuan nilai TAC (Total Antioxidant Capacity) pada sampel dilakukan dengan mencampurkan reagen FRAP dengan ekstrak sampel. Dalam reagen FRAP terdapat campuran TPTZ, $\mathrm{FeCl}_{3}$ dan buffer asetat, sehingga reagen FRAP merupakan senyawa komplek $\mathrm{Fe}^{3+}$-TPTZ yang tidak berwarna (berbeda dengan komplek $\mathrm{Fe}^{2+}$ yang berwarna biru). Senyawa $\mathrm{Fe}^{3+}$-TPTZ mewakili senyawa oksidator yang mungkin terdapat di dalam tubuh dan dapat merusak sel-sel tubuh, sedangkan ekstrak sampel mengandung antioksidan yang kemudian dapat mereduksi $\mathrm{Fe}^{3+}$-TPTZ menjadi $\mathrm{Fe}^{2+}$ TPTZ sehingga senyawa $\mathrm{Fe}^{3+}$-TPTZ tidak akan melakukan reaksi yang merusak sel-sel tubuh. Semakin banyak konsentrasi $\mathrm{Fe}^{3+}$ TPTZ yang direduksi oleh sampel menjadi $\mathrm{Fe}^{2+}$-TPTZ, maka aktivitas antioksidan dari sampel juga semakin besar ${ }^{[20]}$.

Penelitian yang akan dilakukan ini adalah untuk mencari metoda alternatif yaitu dengan cara memodifikasi metoda analisis antioksidan khususnya metoda FRAP dengan mengganti zat yang digunakan yaitu TPTZ dengan orto fenantrolin. Mekanisme yang terjadi adalah $\mathrm{Fe}^{3+}$ dari $\mathrm{FeCl}_{3}$ akan mengoksidasi senyawa yang bersifat antioksidan, akibatnya $\mathrm{Fe}^{3+}$ akan tereduksi dan membentuk $\mathrm{Fe}^{2+} \cdot \mathrm{Fe}^{2+}$ yang terbentuk akan bereaksi dengan orto-fenantrolin sehingga terbentuk senyawa kompleks Fefenantrolin yang berwarna merah. Absorban senyawa kompleks ini diukur dengan alat spektrofotometer UV-Vis. Banyaknya senyawa kompleks yang terbentuk akan sebanding dengan kandungan antioksidan total dalam bahan tersebut.
Validasi metode ini dilakukan pada penentuan kandungan antioksidan dalam sampel mangga dan rambutan. Parameter yang ditentukan adalah linearitas, LoQ (Limit of Quantitation), LoD (Limit of Detection), standar deviasi relatif (SDR), dan persen perolehan kembali

\section{METODOLOGI PENELITIAN}

\section{Bahan Kimia dan Peralatan}

Bahan kimia yang digunakan adalah asam galat (Merck), besi (III) klorida (Merck), orto-fenantrolin (Merck), akuades, kertas saring, rambutan Binjai dan mangga harum manis.

\section{Peralatan}

Peralatan yang dipakai adalah Spektrofotometer UV-Vis (Thermo Scientific Genesys 20), neraca analitik (Mettler AE 200), penyaring vakum, labu semprot, bola hisap, dan peralatan gelas.

\section{Prosedur Penelitian}

\section{Preparasi Sampel}

Sampel daging buah (mangga/rambutan) sebanyak $50 \mathrm{~g}$ ditambahkan $100 \mathrm{~mL}$ akuades lalu diblender. Ekstrak tersebut disaring. Kemudian filtrat dipipet $5 \mathrm{~mL}$ dan diencerkan dengan akuades dalam labu ukur $100 \mathrm{~mL}$.

\section{Pengukuran Kandungan Antioksidan}

Parameter yang dipelajari untuk penentuan kondisi optimum adalah: Panjang gelombang, diukur pada rentang (450-600) nm. Pengaruh konsentrasi $\mathrm{FeCl}_{3}$, dengan variasi konsentrasi $(0,001 ; 0,002 ; 0,003 ; 0,004 ; 0,005 ; 0,01$; $0,02 ; 0,03 ; 0,04 ; 0,05)$ M. Pengaruh waktu, dengan variasi waktu pengukuran $(10,20,30$, $40,50,60,70,80,90)$ menit. Dilakukan pengerjaan ini secara duplo. Pengaruh konsentrasi asam galat, dengan variasi konsentrasi asam galat $\left(0 ; 5 \times 10^{-5} ; 6 \times 10^{-5}\right.$; $\left.7 \times 10^{-5} ; 8 \times 10^{-5} ; 9 \times 10^{-5} ; 1 \times 10^{-4}\right) \mathrm{M}$.

\section{Validasi Metoda Penentuan Antioksidan dengan $\mathrm{FeCl3}$}


Linearitas. Kedalam 5 buah labu ukur 25 $\mathrm{mL}$ masing-masing dimasukkan $5 \mathrm{~mL}$ asam galat dengan variasi konsentrasi $(0 ; 5 \times 10-5$; $6 \times 10-5 ; 7 \times 10-5 ; 8 \times 10-5 ; 9 \times 10-5 ; 1 \times 10-4)$

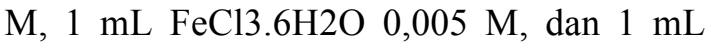
orto-fenantrolin $0,2 \%$. Diencerkan sampai tanda batas dengan akuades dan biarkan selama waktu optimum. Absorban diukur pada panjang gelombang maksimum. Dibuat kurva kalibrasi standar asam galat dengan memplotkan konsentrasi dengan absorban.

Presisi. Ke dalam 5 buah labu ukur $25 \mathrm{~mL}$ masing-masing dimasukkan $5 \mathrm{~mL}$ sampel, 1 $\mathrm{mL} \mathrm{FeCl3.6H2O} \mathrm{0,005} \mathrm{M,} \mathrm{dan} 1 \mathrm{~mL}$ ortofenantrolin $0,2 \%$. Diencerkan sampai tanda batas dengan akuades lalu didiamkan selama waktu optimum. Absorban diukur pada panjang gelombang maksimum. Presisi ditentukan dari nilai simpangan deviasi relatif (SDR) dari hasil-hasil yang diperoleh.

Persen Perolehan Kembali (\% Recovery). Penentuan persen perolehan kembali dikukan dengan pengukuran larutan standar, larutan sampel dan larutan sampel tambah standar.

\section{HASIL DAN PEMBAHASAN}

\section{Panjang Gelombang Maksimum}

Spektrum serapan senyawa kompleks $[\mathrm{Fe}(\mathrm{C} 12 \mathrm{H} 8 \mathrm{~N} 2) 3] 2+$ diukur dengan menggunakan spektrofotometer UV-Vis pada rentang panjang gelombang yang (450-600) nm. Spektrum serapannya dapat dilihat pada Gambar 1.

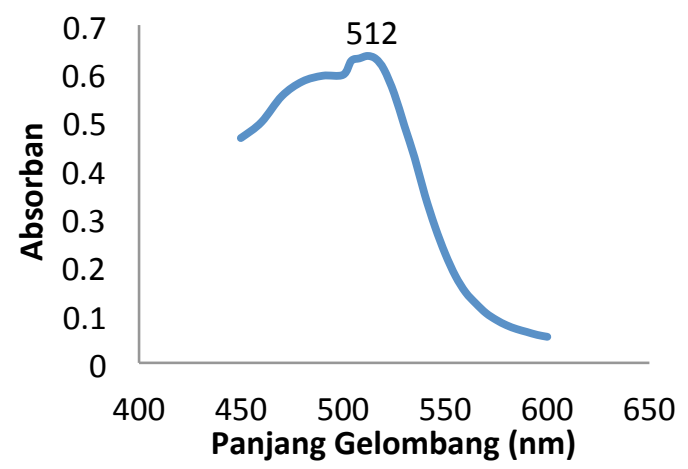

Gambar 1. Spektrum serapan kompleks $\left[\mathrm{Fe}\left(\mathrm{C}_{12} \mathrm{H}_{8} \mathrm{~N}_{2}\right)_{3}\right]^{2+}($ Ket : asam galat $0,0001 \mathrm{M}$, $\mathrm{FeCl}_{3} \cdot 6 \mathrm{H}_{2} \mathrm{O} \quad 0,02 \mathrm{M}$ dan orto-fenantrolin $0,2 \%$ )
Dari Gambar 1 dapat dilihat bahwa serapan maksimum senyawa kompleks $\left[\mathrm{Fe}\left(\mathrm{C}_{12} \mathrm{H}_{8} \mathrm{~N}_{2}\right)_{3}\right]^{2+}$ terjadi pada panjang gelombang $512 \mathrm{~nm}$. Pengukuran selanjutnya dilakukan pada panjang gelombang ini.

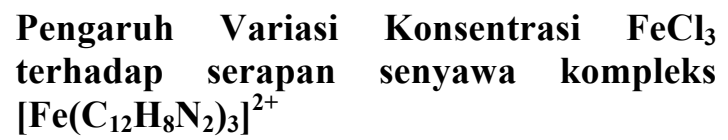

Pengaruh variasi Konsentrasi $\mathrm{FeCl}_{3}$ terhadap serapan senyawa kompleks $\left[\mathrm{Fe}\left(\mathrm{C}_{12} \mathrm{H}_{8} \mathrm{~N}_{2}\right)_{3}\right]^{2+}$ dapat dilihat dari Gambar 2. Nilai absorban naik mulai dari konsentrasi $\mathrm{FeCl}_{3} 0,001$ $\mathrm{M}$ sampai pada $0,005 \mathrm{M}$ dan pada konsentrasi lebih besar dari $0,005 \mathrm{M}$, absorban menurun lagi. Hal ini berarti bahwa pada kisaran konsentrasi $(0,001-$ $0,005) \mathrm{M}$ semua $\mathrm{FeCl}_{3}$ yang tersedia digunakan untuk mengoksidasi antioksidan sehingga terbentuk senyawa kompleks $\left[\mathrm{Fe}\left(\mathrm{C}_{12} \mathrm{H}_{8} \mathrm{~N}_{2}\right)_{3}\right]^{2+}$ berwarna merah yang menaikkan nilai absorban dan mencapai maksimum pada konsentrasi 0,005 M. Pada penambahan $\mathrm{FeCl}_{3}$ dengan konsentrasi yang lebih besar dari 0,005 M menyebabkan penurunan absorban, hal ini kemungkinan disebabkan oleh kelebihan $\mathrm{FeCl}_{3}$ yang berwarna kuning mempengaruhi warna kompleks $\quad\left[\mathrm{Fe}\left(\mathrm{C}_{12} \mathrm{H}_{8} \mathrm{~N}_{2}\right)_{3}\right]^{2+} \quad$ sehingga panjang gelombang maksimum bergeser dan nilai absorban menjadi turun.

\section{Pengaruh Variasi Waktu terhadap Kestabilan Kompleks $\left[\mathrm{Fe}\left(\mathrm{C}_{12} \mathrm{H}_{8} \mathrm{~N}_{2}\right)_{3}\right]^{+2}$}

Kestabilan kompleks $\left[\mathrm{Fe}\left(\mathrm{C}_{12} \mathrm{H}_{8} \mathrm{~N}_{2}\right)_{3}\right]^{2+}$ dipengaruhi oleh waktu seperti yang dapat dilihat pada Gambar 3. Dari data kurva di atas dapat dilihat bahwa terjadi peningkatan nilai absorban pada waktu 10-30 menit. Hal ini berarti bahwa pembentukan senyawa kompleks terus berlangsung sampai 30 menit, namun setelah waktu 30 menit pembentukan senyawa kompleks tidak terjadi lagi yang diperlihatkan dengan nilai absorban yang tidak naik lagi. Nilai absorban ini tidak mengalami perobahan yang berarti sampai waktu 90 menit. Hal ini berarti bahwa pengukuran absorban senyawa kompleks ini dapat dilakukan dalam rentang waktu (30-90) menit, dan senyawa kompleks ini merupakan senyawa yang cukup stabil. 


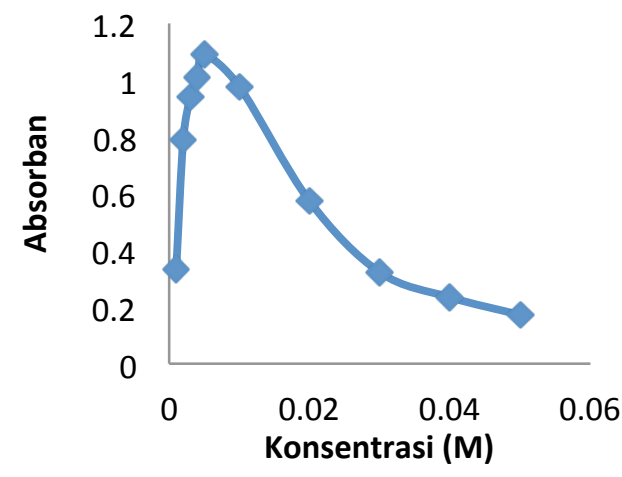

Gambar 2. Pengaruh konsentrasi $\mathrm{FeCl} 3$ terhadap serapan $[\mathrm{Fe}(\mathrm{C} 12 \mathrm{H} 8 \mathrm{~N} 2) 3] 2+$ (Ket: asam galat $0,0001 \mathrm{M}$ dan orto-fenantrolin $0,2 \%)$.

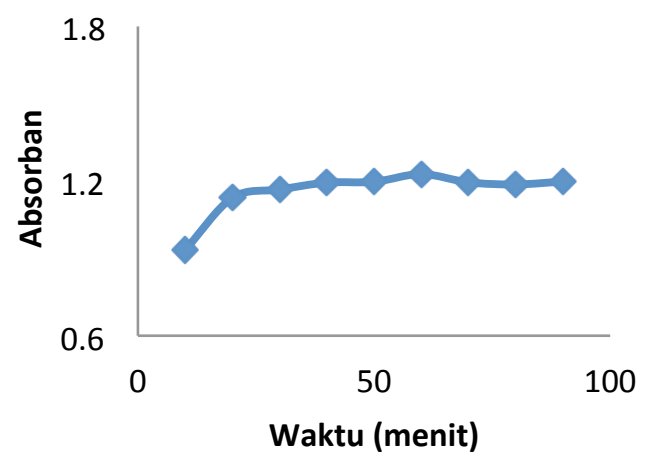

Gambar 3. Kurva Pengaruh Waktu terhadap Kestabilan Kompleks $\left[\mathrm{Fe}\left(\mathrm{C}_{12} \mathrm{H}_{8} \mathrm{~N}_{2}\right)_{3}\right]^{+2}$ (Ket: Asam Galat 0,0001 M ; $\mathrm{FeCl}_{3} 0,005 \mathrm{M}$ dan orto-Fenantrolin 0,2\%).

\section{Validasi Metode}

\section{Linearitas}

Linearitas ini dapat dilihat dari kurva kalibrasi standar. Kurva kalibrasi standar didapatkan dengan cara memplotkan berbagai konsentrasi asam galat (M) dengan hasil pengukuran absorban deretan larutan standar. Kurva kalibrasi standar dapat dilihat pada Gambar 4. Dari kurva kalibrasi standar asam galat di atas dapat dilihat bahwa konsentrasi asam galat sebanding dengan absorbannya. Ini ditunjukkan dengan terjadinya kenaikan absorban pada saat konsentrasi asam galat ditambahkan. Dari kurva kalibrasi standar asam galat tersebut didapatkan persamaan regresi: $\mathrm{Y}=-7,90 \times 10^{-3}+11298,48 \mathrm{X}, \quad$ koefisien korelasi $(\mathrm{r})=0,999$ dan nilai koefisien determinasi $\left(\mathrm{R}^{2}\right)=0,998$. Ini berarti kurva kalibrasi asam galat ini memiliki linearitas yang baik karena memiliki koefisien determinasi $\left(\mathrm{R}^{2}\right)$ mendekati 1 sehingga dapat digunakan sebagai standar untuk penentuan kandungan antioksidan total.

\section{Batas Deteksi (LoD) dan Batas Kuantitasi (LoQ)}

Berdasarkan kurva kalibrasi standar asam galat dengan persamaan regresinya :

$\mathrm{Y}=-7,90 \times 10^{-3}+11298,48 \mathrm{X}$, didapatkan nilai LoD sebesar $3,13 \times 10^{-6} \mathrm{M}$, sedangkan nilai (LoQ) yang didapatkan adalah $1,04 \mathrm{x}$ $10^{-5} \mathrm{M}$.

Dari data yang didapatkan di atas dapat dilihat bahwa penentuan antioksidan total (dihitung sebagai asam galat) dalam sampel mangga dan rambutan dengan menggunakan oksidator $\mathrm{FeCl}_{3}$ dan pengompleks ortofenantrolin dapat terdeteksi dalam konsentrasi yang kecil.

\section{Presisi}

Presisi menunjukan derajat kesesuaian antara hasil uji larutan yang dilakukan secara berulang pada sampel yang diambil dari campuran yang homogen. Nilai presisi didasarkan pada nilai standar deviasi (SD) dan standar deviasi relatif (\%SDR) yang digunakan untuk mengetahui ketepatan ulang metode yang digunakan. Batasan nilai standar deviasi relatif (\%SDR) yang diperbolehkan adalah $5 \%$. Semakin kecil nilai yang didapatkan, maka semakin bagus nilai presisinya. Nilai standar deviasi relatif pada mangga dan rambutan adalah 1,15\% dan 1,34\%. Berdasarkan nilai dari SDR yang didapatkan, maka metode ini sangat tepat untuk menganalisis antioksidan total karena memiliki ketepatan ulangan yang baik.

\section{Perolehan Kembali (Recovery)}

Perolehan kembali (Recovery) digunakan untuk melihat keakuratan metode yang digunakan dengan hasil-hasil yang telah didapatkan. Nilai perolehan kembali yang didapatkan menunjukkan bahwa keakuratan metode pada penentuan konsentrasi antioksidan total dalam sampel cukup tinggi karena nilai recovery yang diperbolehkan menurut literatur adalah $100 \pm 10 \%$. Nilai perolehan kembali pada sampel mangga dan rambutan dilihat pada Tabel 1. 


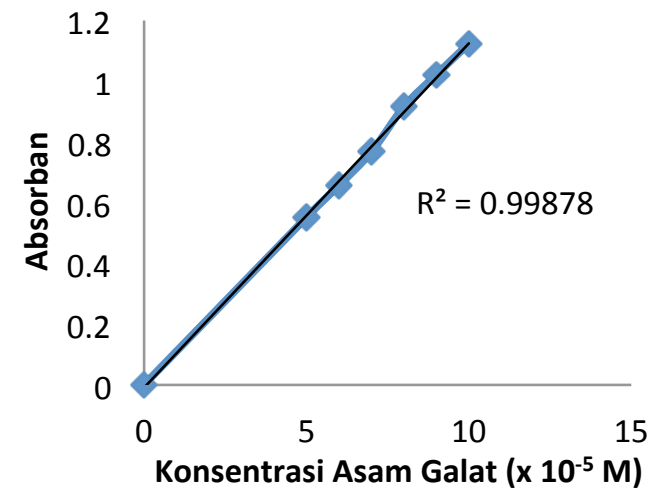

Gambar 4. Kurva kalibrasi standar asam galat

Tabel 1. Nilai perolehan kembali penentuan antioksidan total pada sampel.

\begin{tabular}{ccc}
\hline No & \multicolumn{2}{c}{$\begin{array}{c}\text { \% Perolehan Kembali } \\
\text { (Recovery) }\end{array}$} \\
\cline { 2 - 3 } & Mangga & Rambutan \\
\hline 1 & 97,14 & 98,97 \\
2 & 95,49 & 96,48 \\
Rata - \\
rata
\end{tabular}

Selain itu didapatkan nilai konsentrasi antioksidan total dalam sampel dihitung dari hasil pengukuran absorban konsentrasi sampel pada kurva kalibrasi standar asam galat. Hasil pengukuran antioksidan total pada sampel mangga dan rambutan dapat dilihat pada Tabel 2.

Tabel 2. Konsentrasi antioksidan total (dihitung sebagai asam galat) pada mangga dan rambutan

\begin{tabular}{ccc}
\hline No & \multicolumn{2}{c}{ Konsentrasi Antioksidan (M) } \\
\cline { 2 - 3 } & Mangga & Rambutan \\
\hline 1 & $3,55 \times 10^{-5}$ & $7,41 \times 10^{-5}$ \\
2 & $3,54 \times 10^{-5}$ & $7,42 \times 10^{-5}$ \\
3 & $3,45 \times 10^{-5}$ & $7,52 \times 10^{-5}$ \\
4 & $3,50 \times 10^{-5}$ & $7,57 \times 10^{-5}$ \\
5 & $3,52 \times 10^{-5}$ & $7,64 \times 10^{-5}$ \\
Jumlah & $1,75 \times 10^{-4}$ & $3,76 \times 10^{-4}$ \\
Rata2 & $3,51 \times 10^{-5}$ & $2,92 \times 10^{-5}$ \\
\hline
\end{tabular}

\section{KESIMPULAN}

Dari hasil penelitian yang telah dilakukan dapat diambil kesimpulan bahwa metode penentuan kandungan antioksidan total (dihitung sebagai asam galat) dalam sampel mangga dan rambutan dengan oksidator $\mathrm{FeCl}_{3}$ dan pengompleks orto-fenantrolin telah memenuhi persyaratan validasi yang ditetapkan.

\section{DAFTAR PUSTAKA}

1. K. Mahattanatawee, J.A. Manthey, G. Luzio, S.T. Talcott, K. Goodner, E. A. Baldwin, Total antioxidant activity and fiber content of select Florida-grown tropical fruits, J. Agr. \& Food Chem., 54(19), 7355-7363 (2006)

2. S.M.R. Ribeiro, J.H. Queiroz, M.E.L. Ribeiro de Queiroz , F.M. Campos, H.M.P. Sant'ana, Antioxidant in mango (Mangifera indica L.) pulp. Plant Foods Hum Nutr. 62 (1) : 13-17 (2007)

3. B. Tepe, S. Degerli, S. Arslan, E. Malatyali, C. Sarikurkcu, Determination of chemical profile, antioxidant, DNA damage protection and antiamoebic activities of Teucrium polium and Stachys iberica, Fitoterapia, 82 : 237246 (2011)

4. A. Garcia, M.G. Alriols, G. Spigno, J. Labidi, Lignin as natural radical scavenger. Effect of the obtaining and purification processes on the antioxidant behaviour of lignin, Biochem. Eng. J., 67 : 173- 185 (2012)

5. S. Flis, Z. Jastrzebski, J. Namiesnik, P. Arancibia-Avilac, F. Toledo, $\mathrm{H}$. Leontowicz, M. Leontowicz, M. Suhaj, S. Trakhtenberg, S. Gorinstein, Evaluation of inhibition of cancer cell proliferation in vitro with different berries and correlation with their antioxidant levels by advanced analytical methods, J. Pharm. Biomed. Anal. 62 : 68-78 (2012)

6. G.F. Deng, X.R. Xu, Y.J. Guo, E.Q. Xiaa, S. Lia, S. Wu, F. Chen, W.H. Linga, H. B. Li, Determination of antioxidant property and their lipophilic 
and hydrophilic phenolic contents in cereal grains, J. Func. Food., 4 : $906-$ 914 (2012)

7. P. Biparva, M. Ehsani, M.R. Hadjmohammadi Dispersive liquidliquid microextraction using extraction solvents lighter than water combined with high performance liquid chromatography for determination of synthetic antioxidants in fruit juice samples, J. Food Compos. Anal., 27 : 87-94 (2012)

8. M. Viuda-Martos, Y. Ruiz-Navajas, J. Fernández-López, E. Sendra, E. SayasBarberá, J.A. Pérez-Álvarez, Antioxidant properties of pomegranate (Punica granatum L.) bagasses obtained as co-product in the juice extraction, Food Res. Int., 44 : 1217-1223 (2011)

9. R. Martínez, P. Torres, M.A. Meneses, J.G. Figueroa, J.A. Pérez-Álvarez, M. Viuda-Martos Chemical, technological and in vitro antioxidant properties of cocoa (Theobroma cacao L.) coproducts, Food Res. Int. 49 : 39-45 (2012)

10. E. Bursal, E. Köksal, İ. Gülçin, G. Bilsel, A.C. Gören, Antioxidant activity and polyphenol content of cherry stem (Cerasus avium L.) determined by LCMS/MS, F. Res. Int., 51 : 66-74 (2013)

11. V. Kraujalyte, P.R. Venskutonis, A. Pukalskas, L. Cesoniene, R. Daubaras Antioxidant properties, phenolic composition and potentiometric sensor array evaluation of commercial and new blueberry (Vaccinium corymbosum) and bog blueberry (Vaccinium uliginosum) genotypes, Food Chem.188 : 583-590 (2015)

12. M. R. Loizzo, A. Pugliese, M. Bonesi, F. Menichini, R. Tundis, Evaluation of chemical profile and antioxidant activity of twenty cultivars from Capsicum annuum, Capsicum baccatum, Capsicum chacoense and Capsicum chinense: A comparison between fresh and processed peppers, LWT - Food Sci. Techn., 64 : 623-631 (2015)

13. T.D.T. Do, D. Cozzolino, B. Muhlhausler, A. Box, A.J. Able,
Antioxidant capacity and vitamin $\mathrm{E}$ in barley: Effect of genotype and storage, Food Chem.,187 : 65-74 (2015)

14. A. Szydłowska-Czerniak, A. Łaszewska, Effect of refining process on antioxidant capacity, total phenolics and prooxidants contents in rapeseed oils, LWT - Food Sci. Tech., 64 : 853-859 (2015)

15. A. Szydłowska-Czerniak, A. Tułodziecka, Comparison of a silver nanoparticle-based method and the modified spectrophotometric methods for assessing antioxidant capacity of rapeseed varieties, Food Chem., 141:1865-1871 (2013).

16. T. Alfonso de Araujo, A.M.J.Barbosa, L.H. Viana, V.S. Ferreira Electroanalytical determination of TBHQ , a synthetic antioxidant, in soybean biodiesel samples, Fuel 90 : 707-712 (2011).

17. S.S. Marques, I.V. Tóth, L.M. Magalhães, S. Reis, M.A. Segundo, High-sensitivity programmable flow method for assessment of total antioxidant capacity in biological samples, Microchem. J., 124: 261-266 (2016)

18. P. Biparva, M. Ehsani, M.R. Hadjmohammadi, Dispersive liquidliquid microextraction using extraction solvents lighter than water combined with high performance liquid chromatography for determination of synthetic antioxidants in fruit juice samples, J. Food Compos. Anal. 27 : 87-94 (2012).

19. A. Aktas_Karacelik, M. Kucuk, Z. Iskefiyeli, S. Aydemir, S. De Smet, B. Miserez , P. Sandra, Antioxidant components of Viburnum opulus L. determined by on-line HPLC-UVABTS radical scavenging and $\mathrm{LC}-\mathrm{UV}-$ ESI-MS methods, Food Chem., 175 : 106-114 (2015)

20. M. Pisoschi1, G.P. Negulescu, Methods for Total Antioxidant Activity Determination: A Review, Biochem \& Anal Biochem, 1:1, 1-10 (2011) . 